DOI: $10.17951 / 1 r p .2019 .38 .3 .237-253$

\author{
Janusz Piotr TomiŁo \\ Uniwersytet Jana Kochanowskiego w Kielcach \\ Filia w Piotrkowie Trybunalskim \\ Wydział Nauk Społecznych
}

\title{
NIEKTÓRE UWARUNKOWANIA AKTYWNOŚCI EDUKACYJNEJ DOROSŁYCH
}

Streszczenie: Obserwowany od lat niski wskaźnik aktywności edukacyjnej dorosłych skłania do podjęcia refleksji nad przyczynami tego zjawiska - postawienia diagnozy, która mogłaby stać się kanwą działań zmierzających do likwidacji tych przyczyn. W artykule skoncentrowano się na próbie ukazania uwarunkowań aktywności edukacyjnej dorosłych. Uznano, że znaczącą rolę odgrywają tu dwa rodzaje czynników: (1) związane z poczuciem bezpieczeństwa: osobistego, pracy czy edukacyjnego oraz (2) związane z kapitałem kulturowym jednostki. Poczucie bezpieczeństwa identyfikowane jest przez pryzmat stanu środowiska bezpieczeństwa, statusu i sytuacji społecznej oraz kompetencji jednostki i poczucia kontroli na własnym życiem i losem, a także osobowości dorosłego. Stan środowiska bezpieczeństwa został ukazany w perspektywie społecznej poprzez powiększającą się strefę ubóstwa, rozwarstwienie i polaryzację społeczną, marginalizację i wykluczenie społeczne oraz dyskryminacyjne formy zatrudnienia, naruszające prawa pracownicze i malejący przyrost naturalny, zmuszający pracowników do przedłużania okresu zatrudnienia, szczególnie w sytuacji coraz większej niewydolności systemu zabezpieczeń społecznych. Zaproponowano spojrzenie na aktywność edukacyjną dorosłych przez pryzmat dominacji potrzeb rynku pracy, ale także wydłużającego się życia Polek i Polaków. Natomiast znaczenie kapitału kulturowego przejawia się w stratyfikacji społecznej: w społeczeństwach postkomunistycznych nabywanie kapitału kulturowego jest bowiem postrzegane jako droga do awansu społecznego, ponieważ o stratyfikacji społecznej nie decyduje zarówno odziedziczony kapitał ucieleśniony (inkorporowany), jak i uprzedmiotowiony (zobiektywizowany). W tej sytuacji największe znaczenie ma kapitał zinstytucjonalizowany, głównie w postaci sformalizowanego wykształcenia, potwierdzonego dyplomami uczelni. Ukształtowana w PRL ścieżka awansu, osadzona w wykształceniu, opierała się na antynomii: praca fizyczna versus praca umysłowa, z których to ta druga nobilitowała. Zdobycie wykształcenia, najlepiej wyższego, było substytutem nobilitacji opartej na tzw. starych pieniądzach czy budowanej przez pokolenia pozycji zawodowej.

Słowa kluczowe: edukacja dorosłych, poczucie bezpieczeństwa, kapitał kulturowy, aktywność edukacyjna dorosłych 


\section{WPROWADZENIE}

W rozważaniach nad aktywnością edukacyjną dorosłych dominuje podejście statystyczno-porównawcze. Prezentowanym w różnych opracowaniach danym statystycznym towarzyszy ocena poziomu aktywności i porównanie do wskaźników, nie tylko z minionych okresów, lecz także innych państw lub grup państw. Przykładem jest analiza skali uczestnictwa w kształceniu osób w wieku 25-64 lata dokonana przez Główny Urząd Statystyczny, która wskazuje, że w porównaniu z 2006 rokiem w 2011 roku wskaźnik uczestnictwa dla tej grupy wiekowej w jakiejkolwiek formie kształcenia wzrósł o 4,2\%. Coraz więcej osób bierze udział w kształceniu pozaformalnym (wzrost z 18,6\% w 2006 do 21\% w 2011 roku) oraz nieformalnym (wzrost z 25,4\% do 29,0\%). Spada natomiast wskaźnik uczestnictwa w kształceniu formalnym, który dla 2006 roku wynosił 5,5 \%, dla 2011 roku 5,4\%, ale już w 2015 roku wyniósł 3,5\% (3,3\% kobiet i 3,8\% mężczyzn), przy średniej dla krajów UE wynoszącej 10,7\% (Monitor... 2015, s. 8). Jednocześnie odsetek osób dorosłych (w wieku 18-59/64) w Polsce, które w 2014 roku zgłosiły, że uczestniczyły w ciągu ostatnich 12 miesięcy w jakiejś formie kształcenia lub szkolenia (szkolenia, kształcenia formalnego, pozaformalnego lub nieformalnego), pozostawał niemal bez zmian i wynosił 37\% (GUS 2013, s. 16). W zakresie umiejętności podstawowych, mimo że w Polsce tylko około 10\% dorosłych nie ukończyło edukacji na poziomie szkolnictwa średniego II stopnia (licea i technika), to aż 18,8\% ma niski poziomi umiejętności czytania i pisania, a 23,5\% ma niski poziomi umiejętności liczenia (Komisja Europejska 2015, s. 21).

Na dane te można spojrzeć z dwóch punktów widzenia: (1) wypracowania strategii zwiększenia aktywności edukacyjnej dorosłych, osiągnięcia wskaźników bliskich przynajmniej średniej unijnej, a także podniesienia poziomu ich umiejętności podstawowych, oraz (2) strategii likwidacji przyczyn słabej aktywności edukacyjnej dorosłych. W niniejszym opracowaniu podjęto próbę zwrócenia uwagi na ten drugi aspekt, szczególnie zaś znaczenia poczucia bezpieczeństwa, w tym głównie osobistego i edukacyjnego dla uczestnictwa w edukacji oraz na problem roli kapitału kulturowego w aktywności edukacyjnej dorosłych.

\section{ISTOTA BEZPIECZEŃSTWA}

Pojęcie bezpieczeństwa ma jedno z najszerszych znaczeń, spośród pojęć znanych człowiekowi, a przy tym różnie przez niego interpretowanych - w zależności od: miejsca, czasu czy charakteru zagrożeń. Według Barry’ego Buzana idea bezpieczeństwa tkwi korzeniami w początkach dziejów myśli ludzkiej (Buzan 1983; 
Stańczyk 1996). Wówczas bezpieczeństwo nie miało tak wysokiej pozycji, jak obecnie, ginęło wśród innych, ważniejszych kategorii oraz wartości związanych $\mathrm{z}$ istnieniem i działaniem człowieka. Dziś bezpieczeństwo staje się najważniejszą wartością nie tylko w obszarze historii, pedagogiki, stosunków międzynarodowych, politologii, ekonomii, dyscyplin szczegółowych czy kierunków refleksji filozoficznej (m.in. uniwersalizm, ekofilozofia, psychofizjologia), ale także nauk przyrodniczych, medycznych i technicznych ${ }^{1}$.

Ken Booth wiąże bezpieczeństwo $\mathrm{z}$ wolnością człowieka, jego emancypacją. Pisze: „Bezpieczeństwo oznacza nieobecność zagrożeń. Emancypacja to wyzwolenie ludzi (jednostek i grup) od tych fizycznych i ludzkich ograniczeń, jakie powstrzymują je od tego, co mając wolny wybór, wybrałyby. Wojna oraz jej groźba jest jednym z takich ograniczeń, obok biedy, braku edukacji, politycznych prześladowań itd. Bezpieczeństwo i emancypacja są dwoma stronami tej samej monety. Emancypacja, nie potęga lub porządek, tworzy prawdziwe bezpieczeństwo. Emancypacja, teoretycznie, jest bezpieczeństwem" (Booth 1991, s. 319).

Słowa Bootha korespondują z sytuacją w Syrii czy na Ukrainie: w obu przypadkach działania polityków, zmierzające do umocnienia swojej potęgi i zaprowadzenia własnego porządku, stały się bezpośrednią przyczyną konfliktów społecznych, które przybrały postać, w przypadku Syrii - wojny domowej, zmuszającej ponad 2 mln obywateli do opuszczenia własnego domu i kraju, w przypadku Ukrainy do wielomiesięcznych demonstracji, zakończonych próbą krwawego rozprawienia się z manifestantami. Brak możliwości wyboru innego sposobu życia $\mathrm{w}$ innych uwarunkowaniach społeczno-politycznych doprowadził do eskalacji zagrożenia naruszającego nie tylko bezpieczeństwo poszczególnych obywateli, lecz także całego państwa. Taka sytuacja rodzi pytania: jak daleko można się posunąć w walce o, często iluzoryczną, poprawę sytuacji? Czy walka o emancypację może usprawiedliwiać naruszenie bezpieczeństwa w warunkach jej (emancypacji) braku? Na ile walka o prawa człowieka jest etyczna, skoro żadna wojna etyczna nie jest? Czy drogą do osiągnięcia bezpieczeństwa może być walka? Paradoks czy ponowne odwołanie się do si vis pacem, para bellum? Militarystyczna retoryka przeraża antycypowaną treścią i metodą uzyskiwania bezpieczeństwa, tkwiącym w nich paradoksem i wydawać by się mogło beznadzieją w coraz częściej zadawanym pytaniu: jak żyć w XXI wieku?

Próbę odpowiedzi na to pytanie podjęli autorzy Human Development Report (HDR 1994) z 1994 roku, przewidując, że w XXI wieku idea bezpieczeństwa ludzi

${ }^{1}$ Z nauk przyrodniczych i technicznych oraz teorii niezawodności systemów i urządzeń technicznych wyrasta teoria, wiążąca bezpieczeństwo z cybernetycznym postrzeganiem niezawodności systemów. 
w naturalny sposób może zrewolucjonizować społeczeństwo. W analizie pojęcia bezpieczeństwa ludzi skupili się na jego czterech podstawowych cechach:

1. Uniwersalizmie bezpieczeństwa ludzi jako problemie istotnym dla ludzi na całym świecie, zarówno dla bogatych, jak i ubogich. Istnieje wiele zagrożeń, które są wspólne dla wszystkich ludzi, takich jak bezrobocie, narkotyki, przestępczość, zanieczyszczenie środowiska i łamanie praw człowieka. Natężenie ich występowania może być różne w różnych częściach świata, ale wszystkie te zagrożenia dla bezpieczeństwa ludzi są realne, bliskie i wciąż narastają.

2. Współzależności składników bezpieczeństwa. Kiedy bezpieczeństwo ludzi jest zagrożone na całym świecie, wszystkie państwa mogą zaangażować się w zapewnianie bezpieczeństwa. Głód, przestępczość, zanieczyszczenie środowiska, handel narkotykami, terroryzm, spory etniczne i dezintegracja społeczna nie są pojedynczymi wydarzeniami w ramach zamkniętych granic państwowych. Ich konsekwencje dotyczą całego globu.

3. Zapewnianiu bezpieczeństwa człowieka poprzez wczesne zapobieganie, które jest łatwiejsze niż późniejsza interwencja. Profilaktyka jest mniej kosztowna.

4. Bezpieczeństwo ludzi dotyczy tego, jak ludzie żyją w społeczeństwie, jak wielu mogą dokonywać wolnych wyborów, jaki mają dostęp do rynku i możliwości społecznego rozwoju, przede wszystkim zaś czy żyją w konflikcie lub w pokoju.

Według autorów raportu próba sformułowania definicji bezpieczeństwa, na takich zasadach, jak definicji wolności jednostki ludzkiej, jest niemożliwa. Bezpieczeństwo ludzkie bowiem łatwiej można zidentyfikować przez jego nieobecność niż obecność. Większość ludzi instynktownie tak to rozumie. Stąd najczęściej pojęcie to oznacza: (1) wolność od takich przewlekłych zagrożeń, jak głód, choroby i represje; (2) ochronę przed nagłymi i naruszającymi codzienne wzorce życia zagrożeniami, w domach, w pracy lub w społeczności. Zagrożenia tego typu mogą występować na wszystkich poziomach dochodów i rozwoju kraju. Autorzy raportu konstatują, że myślenie o bezpieczeństwie musi się zmienić na dwa podstawowe sposoby: (1) od wyłącznego nacisku na bezpieczeństwo terytorialne do zwiększenia presji na budowę bezpieczeństwa człowieka; (2) od bezpieczeństwa poprzez zbrojenia do bezpieczeństwa poprzez zrównoważony rozwój człowieka (HDR 1994, s. 22-23).

Samo pojęcie „bezpieczeństwo”, co warto podkreślić, jest neutralne ideologicznie, i - jak pisze Witold Pokruszyński (Pokruszyński 2010, s. 9) - powszechnie rozumiane jako stan: spokoju, pewności, wolności od zagrożeń, strachu lub ataku. Biorąc pod uwagę takie uniwersalne rozumienie bezpieczeństwa, można stwierdzić, że bezpieczeństwo dotyczy: 
- człowieka posiadającego system własnych wartości i dóbr (materialnych i niematerialnych), które z jego punktu widzenia wymagają odpowiedniego zabezpieczenia, ochrony i obrony (bezpieczeństwo indywidualne);

- grup ludzi (grup społecznych), sformalizowanych (rodzina) oraz niesformalizowanych (grupy etniczne, narodowościowe, wspólnoty religijne i wyznaniowe), lecz mających na ogół wspólne potrzeby godne ochrony;

- organizacji tworzonych przez ludzi, działających w sferze gospodarczej, politycznej (partie polityczne), społecznej, kulturalnej itp.;

- sformalizowanych i terytorialnie rozpoznawalnych struktur, które kierują się określonymi prawami, takich jak: gmina, powiat województwo, państwo, grupa państw (Gardocki 1999).

W odniesieniu do człowieka można mówić o bezpieczeństwie osobistym, rozumianym jako taki stan prawny i organizacyjny środowiska (m.in. społecznego, kulturowego, przyrodniczego, gospodarczego) człowieka (jednostki), który zapewnia mu trwanie i przetrwanie oraz realizację jego praw podstawowych i możliwość wszechstronnego rozwoju. Jest to podstawowy wymiar bezpieczeństwa, konstytutywny i deterministyczny w perspektywie codziennej aktywności człowieka. Bezpieczeństwo osobiste stanowi fundament poczucia bezpieczeństwa i wywołuje potrzebę zapewnienia bezpieczeństwa $w$ innych sferach. W innym ujęciu, jako bezpieczeństwo człowieka (human safety) (bezpieczeństwo jednostki ludzkiej), jest to, akcentując aspekt humanitarny wszelakich konfliktów i katastrof, stawiając życie i jednostkę ludzką w centrum zainteresowania oraz odrzucając „wąskie” pojmowanie pojęcia bezpieczeństwa, stan i proces, którego celem jest nie tylko biologiczne przeżycie, ale również możliwość rozwoju, nieskrępowanego uczestnictwa w życiu publicznym, dążenie do szczęścia, samorealizacji itp., poczucia wolności od niedostatku i wolności od strachu (por. Urbanek 2013, s. 53 i nn.)

Według Abrahama Maslowa (Maslow 2009, s. 66) bezpieczeństwo jest drugą, po zaspokojeniu fizjologicznych, potrzebą człowieka. Maslow podkreśla, że pokojowe, sprawnie funkcjonujące, trwałe, dobre społeczeństwo zapewnia zwykle swoim członkom wystarczające poczucie bezpieczeństwa, chroniąc ich przed dzikimi zwierzętami, krańcowymi zmianami temperatury, napadem kryminalnym, morderstwem, chaosem, tyranią itd. Dlatego też, w bardzo realnym znaczeniu, nie odczuwają oni już żadnych potrzeb bezpieczeństwa jako czynnych motywatorów. Tak samo jak najedzony człowiek nie odczuwa głodu, człowiek bezpieczny nie czuje się zagrożony (Maslow 2009, s. 66).

Potrzeba bezpieczeństwa stanowi aktywny i dominujący czynnik mobilizujący zasoby organizmu człowieka wyłącznie w sytuacjach rzeczywiście krytycznych, takich jak wojna, choroba, katastrofy żywiołowe, napady, zamęt społeczny, nerwica, urazy mózgu, upadek autorytetu, długotrwałe trudne sytuacje (Maslow 2009, 
s. 67). Potrzeba bezpieczeństwa staje się bardzo paląca w życiu społecznym, ilekroć powstaje rzeczywiste zagrożenie prawa, porządku, władzy. Można się spodziewać, że u większości istot ludzkich zagrożenie chaosem czy nihilizmem spowoduje regresję od wszelkich potrzeb wyższego rzędu do silniejszych potrzeb bezpieczeństwa. Równocześnie jednak zaspokojenie potrzeb fizjologicznych i bezpieczeństwa jest warunkiem odczuwania potrzeb wyższych, a dążenie do ich zaspokojenia ma pożądane następstwa obywatelskie i społeczne (Korzeniowski 2008, s. 89).

\section{POCZUCIE BEZPIECZEŃSTWA}

Z potrzebą bezpieczeństwa wiąże się poczucie bezpieczeństwa oznaczające świadomość poziomu własnego bezpieczeństwa, a także zdolność jego odczuwania, odbierania. Czuć się bezpiecznie to znaczy nie obawiać się utraty czegoś ważnego i wartościowego dla człowieka, np. zdrowia, życia, spokoju, pracy, rodziny czy dóbr materialnych. Według Norberta Sillamy poczucie bezpieczeństwa „oznacza spokój ducha wywołany przekonaniem, że nie należy się niczego obawiać” (Sillamy 1996, s. 210). Zdaniem Ewy M. Marciniak: „Poczucie bezpieczeństwa jest rozumiane jako fizyczne i psychiczne odczuwanie spokoju i pewności, tworzonych np. przez brak zdarzeń niebezpiecznych lub redukcje ryzyka i niepewności” (Marciniak 2009, s. 59). Poczucie bezpieczeństwa jest stanem doświadczania spokoju, pewności, odczuwania braku zagrożeń, a także przekonania o dysponowaniu wystarczającymi zasobami do działań podmiotowych. Jest to stan przeżywania satysfakcji, zadowolenia wynikającego z posiadania określonego (wystarczającego z punktu widzenia jednostki) poziomu bezpieczeństwa (Klamut 2012, s. 46). Poczucie bezpieczeństwa jest efektem określonych działań pozwalających zaspokoić potrzeby bezpieczeństwa i realizować wartości. Jednocześnie jest także efektem procesu oceny sytuacji, w której człowiek się znajduje: społecznej, gospodarczej, politycznej itp. (Klamut 2012, s. 46)

Poczucie bezpieczeństwa jest zjawiskiem samym w sobie bardzo złożonym, można jednak przyjąć, że wpływa na nie: (1) Wiedza o istniejących zagrożeniach. O stopniu poczucia bezpieczeństwa decyduje głownie jakość wiedzy o możliwych lub realnych zagrożeniach, o środkach i sposobach zapewnienia bezpieczeństwa, znajomość systemu ochrony bezpieczeństwa (np. instytucji i organizacji odpowiedzialnych za bezpieczeństwo pracy czy przestrzeganie praw człowieka i obywatela), umiejętność rozpoznawania zagrożeń, przeciwdziałania im, a także niwelowania przesłanek ich powstawania. (2) Stan środowiska bezpieczeństwa. Stabilna i przewidywalna sytuacja polityczna, społeczna i gospodarcza kraju, regionu czy środowiska lokalnego, a także jednostki, sprzyja podejmowaniu przez jednostki 
wielorakiej aktywności, koncentrowaniu się na realizacji założonego planu życiowego. Zmiana sytuacji życiowej, np. utrata pracy czy konieczność imigracji, jest destabilizująca, zmuszająca do budowania na nowo fundamentów bezpieczeństwa. Pogorszenie się lub zły stan środowiska naturalnego wyzwala obawę o stan zdrowia, itp. (3) Status, sytuacja społeczna jednostki. Jak pisze Sillamy: „Dziecko odnajduje poczucie bezpieczeństwa dzięki pełnej spokoju i miłości obecności rodziców, stabilności warunków swego życia, wychowaniu w systematyczności umiarkowanej dyscyplinie. [...] W okresie dorastania trudniej odnaleźć poczucie bezpieczeństwa, gdyż nie będąc już dzieckiem ani jeszcze dorosłym, nie posiada się określonego statusu. U człowieka dorosłego konformizm społeczny jest środkiem zachowania poczucia bezpieczeństwa" (Sillamy 1996, s. 210-211). Afiliacja, poczucie zakorzenienia $\mathrm{w}$ określonym środowisku i więzi z nim (rodziną, grupą sąsiedzką, środowiskiem lokalnym itp.), świadomość, że jest ktoś, na kogo jednostka może liczyć, podnosi komfort psychiczny w codziennym życiu i poczucie bezpieczeństwa. Pozycja społeczna i pełniona przez jednostkę rola w znaczący sposób mogą wpływać na jej postrzeganie bezpieczeństwa, a tym samym na poczucie bezpieczeństwa. (4) Kompetencje jednostki i poczucie kontroli nad własnym życiem i losem. Im większa samodzielność i poczucie panowania nad własnym losem, wiedza i umiejętności organizowania sobie życia i bezpiecznego środowiska, a także przekonanie o własnym wpływie na nie, tym wyższe poczucie bezpieczeństwa. (5) Osobowość. Ukształtowane w okresie wczesnego dzieciństwa wzory odbioru otaczającej rzeczywistości, zaufanie lub wręcz przeciwnie - nieufność wobec otaczającego świata, może prowadzić do przekonania, że otoczenie społeczne stanowi dla jednostki zagrożenie. Skłonność do doświadczania lęku i strachu, do ryzyka, zaniżona samoocena i brak poczucia tożsamości, obok neurotyczności, stanowią istotne czynniki wpływające na poczucie bezpieczeństwa przez jednostkę (Tomiło 2015, s. 49-50).

Oprócz teorii potrzeb Maslow wprowadził do psychologii pojęcia syndromu poczucia bezpieczeństwa i braku poczucia bezpieczeństwa, sugerując, że trzeba badać jego rolę dla całej osobowości. Odwołując sie do swojej koncepcji hierarchii potrzeb, podał symptomy syndromu poczucia bezpieczeństwa, z których za źródła syndromu poczucia bezpieczeństwa - poczucia niebezpieczeństwa uznał symptomy: (1) poczucie bycia lubianym, akceptowanym, traktowym serdecznie; (2) poczucie przynależności, bycia w świecie jak u siebie, bycia na własnym miejscu, zajmowania swego miejsca grupie; (3) poczucie bezpieczeństwa, poczucie zaufania do siebie. Uzupełnił je o symptomy będące cechami uzupełniającymi, wtórnymi, tzn. skutkami udaremnienia lub zaspokojenia pierwotnych trzech źródłowych potrzeb. W przypadku syndromu poczucia bezpieczeństwa są to cechy mające charakter głębokich charakterologicznych postaw (symptomy), 
takie jak: (1) postrzeganie świata i życia jako czegoś przyjemnego, przyjacielskiego, życzliwego i serdecznego; (2) postrzeganie innych jako istot $\mathrm{z}$ natury dobrych, miłych, przyjacielskich życzliwych i serdecznych; (3) uczucie przyjaźni i zaufania do innych, mało wrogości, a raczej tolerancja w stosunku do innych, spontaniczne wyrazy serdeczności; (4) optymistyczne nastawienie, przewidywanie pomyślnych wydarzeń; (5) spontaniczność w funkcjonowaniu, zdolność do ukierunkowania sie na świat i innych niż na własne Ja; (6) akceptacja siebie i własnej impulsywności. Do reaktywnych zachowań (symptomów) zaliczane są takie skłonności, jak: (7) poczucie zadowolenia i osobistego szczęścia; (8) poczucie wyciszenia sie i spokoju, relaksu, bezkonfliktowości, emocjonalnej stabilności; (9) brak neurotycznych czy psychotycznych zachowań, realistyczne radzenie sobie w życiu; (10) gotowość do współpracy, zainteresowanie innymi, sympatia (Uchnast 1990, s. 95-108).

Z kolei syndrom zaburzonej potrzeby poczucia bezpieczeństwa zaproponowany przez Maslowa jako przeciwstawny do adekwatnego poczucia bezpieczeństwa charakteryzuje się: (1) poczuciem braku akceptacji, bycia odrzuconym, niekochanym, traktowanym z chłodem i bez uczuć życzliwości, bycia pogardzanym, nienawidzonym; (2) poczuciem izolacji, wyobcowania, samotności, poczucie wyodrębnienia sie, jedyności; (3) stałym poczuciem niepokoju, zagrożenia i możliwości niebezpieczeństwa. Wtórnymi cechami syndromu braku poczucia bezpieczeństwa, mającymi charakter głębokich charakterologicznych postaw (symptomów), są: (4) postrzeganie świata i życia jako czegoś niebezpiecznego i wrogiego; (5) postrzeganie innych jako istot z natury złych, złośliwych i egoistycznych, jako niebezpiecznych, przesądnych i nienawistnych; (6) poczucie braku zaufania, niechęci i zazdrości względem innych; (7) pesymistyczne nastawienie do świata, przewidywanie tego, co najgorsze; (8) tendencje do kompulsywnego analizowania swych przeżyć i odczuć; (9) poczucie zniechęcenia, winy, wstydu i grzeszności. Do reaktywnych zachowań (symptomów) zaliczane są takie skłonności, jak: (10) skłonność do poczucia niezadowolenia i zawiedzenia; (11) poczucie napięcia, pobudzenia i stanu konfliktu, co przejawia sie w ogólnej „,nerwowości”; (12) zaburzenia w zakresie oceny samego siebie; (13) stała potrzeba zapewnienia sobie poczucia bezpieczeństwa, neurotyczne tendencje do postaw obronnych, ucieczki skłonności do zachowań psychotycznych; (14) tendencje do zachowań samolubnych egocentrycznych, indywidualistycznych (Wójcik 2003, s. 261).

Postrzeganie i identyfikowanie bezpieczeństwa, a przede wszystkim poczucie bezpieczeństwa, uwarunkowane jest charakterem i skalą zagrożeń występujących w środowisku bezpieczeństwa. W sferze społecznej będą to przede wszystkim: A. Powiększająca się strefa ubóstwa, rozwarstwienie i polaryzacja społeczna, która - jak się wydaje - jest najpoważniejszym wyzwaniem i zagrożeniem bez- 
pieczeństwa, nie tylko w Polsce, ale i całej Unii Europejskiej. Z danych Eurostatu (www.epp.eurostat.ec.europa.eu) wynika, że w 2012 roku zagrożonych ubóstwem lub wykluczeniem społecznym było 124,5 mln osób, czyli $24,8 \%$ populacji UE. Dla porównania, w 2011 roku problem dotyczył 24,3\% Europejczyków, a w 2007 roku - 23,7\%. W 2012 roku największy procent osób zagrożonych ubóstwem lub wykluczeniem społecznym odnotowano w Bułgarii (49\%), Rumunii (42\%) i Grecji (35\%). W grupie ryzyka znalazło się najmniej obywateli Holandii i Czech (po 15\%) oraz Finlandii (17\%). Polska jest na 19. miejscu z 26,7\% osób zagrożonych. To wynik lepszy niż w poprzednich latach: w 2011 roku zagrożonych było $27,2 \%$ osób, a w 2008 roku - 30,5\%. Najwięcej Polaków jest zagrożonych, bo mają dochód poniżej progu ubóstwa - to $17,1 \%$ całej grupy ryzyka. Brak możliwości zaspokojenia swoich elementarnych potrzeb materialnych to problem 13,5\% mieszkańców, a osoby żyjące w gospodarstwach domowych o bardzo niskiej intensywności pracy to 6,8\% grupy. Nierówności w Europie są największe - $\mathrm{z}$ jednej strony swoich elementarnych potrzeb materialnych nie może zaspokoić $1 \%$ Szwedów i Luksemburczyków, z drugiej - 44\% Bułgarów, 30\% Rumunów i 26\% Litwinów i Węgrów. Z kolei rozwarstwienie społeczne w USA wynosi jak 1 : 11, we Francji 8\% najbogatszych obywateli ma 75\% udział w konsumpcji, w 20\% najbiedniejszych państwach świata ludzie żyją za mniej niż 1 dol. dziennie. B. Marginalizacja i wykluczenie społeczne. Marginalizacja to proces prowadzący do uniemożliwienia grupom lub jednostkom dostępu do ważnych pozycji i symboli władzy gospodarczej, religijnej lub politycznej, natomiast wykluczenie jest pojęciem przeciwstawnym do społecznego uczestnictwa w szerszych zbiorowościach: narodzie, społeczeństwie czy społeczności. Oznacza ono izolację dobrowolną bądź częściej wymuszoną uwarunkowaniami zewnętrznymi (biedą, bezrobociem, odmiennym kolorem skóry, religią, kalectwem, nieakceptowanym przez środowisko zachowaniem czy preferencjami seksualnymi). Pojęcie wykluczenia społecznego (1) odnosi się do życia poza nawiasem praw i przywilejów społeczeństwa; (2) jest ono strukturalną, stratyfikacyjną cechą określonej zbiorowości; (3) nie tylko charakteryzuje statyczny stan rzeczy, ale jest kwintesencją określonego procesu (Jarosz 2008, s. 10). Do grup narażonych na wykluczenie społeczne zalicza się: dzieci i młodzież ze środowisk zaniedbanych i wychowujące się poza rodziną; kobiety samotnie wychowujące dzieci i pozostające poza rynkiem pracy; ofiary patologii życia rodzinnego; osoby o niskich kwalifikacjach lub bezrobotne; żyjących w bardzo trudnych warunkach mieszkaniowych; niepełnosprawnych i chronicznie chorych; osoby chorujące psychicznie; starsze osoby samotne; opuszczających zakłady karne; imigrantów; osoby należące do romskiej mniejszości etnicznej (zob. Narodowa Strategia... 2003). Zjawisko marginalizacji i wykluczenia społecznego jest przedmiotem badań socjologicznych, ale także pedagogicznych, ponie- 
waż zakłóca proces edukacji, utrudnia lub wręcz uniemożliwia jednostkom i grupom społecznym udział w budowaniu społeczeństwa obywatelskiego, a także branie odpowiedzialności za bezpieczeństwo, będąc go w zasadzie pozbawionym. C. Dyskryminacyjne formy zatrudnienia, naruszające prawa pracownicze, które doprowadziły do powstania nowej grupy społecznej - prekariatu. Zdaniem Guy’a Standinga (Standing 2017) „prekariat” to odrębna grupa socjoekonomiczna, klasa w procesie tworzenia, ale jeszcze nie klasa dla siebie w marksowskim sensie tego pojęcia. To kategoria społeczna charakterystyczna dla okresu późnego kapitalizmu. Pojęcie „prekariat” jest neologizmem łączącym przymiotnik „niepewny” (ang. precarious) z rzeczownikiem „proletariat”. Prekariusze to osoby zatrudnione na podstawie elastycznych form zatrudnienia, pozbawione siedmiu gwarancji zatrudnienia: (1) gwarancji rynku pracy, czyli odpowiednich możliwości pracy; (2) gwarancji zatrudnienia - odpowiednia ochrona pracownika przed zwolnieniem i stosowne dostosowanie w tym względzie przepisów prawnych; (3) gwarancji pracy - gwarancja związana z wykonywaniem danej pracy, z pewnością wykonywania takich, a nie innych obowiązków; (4) gwarancji bezpieczeństwa w pracy szeroko pojęta ochrona zdrowia pracownika; (5) gwarancji reprodukcji umiejętności - zapewnienie nauki zawodu, szkoleń, jak i właściwego wykorzystania nabytych umiejętności w pracy; (6) gwarancji dochodu - dopasowana do wykonywanej pracy stała pensja; (7) gwarancji reprezentacji - gwarancja przedstawicielstwa interesów pracownika, na przykład bycie członkiem niezależnego związku zawodowego. Prekariusz żyje w ciągłej niepewności, trudno mu cokolwiek zaplanować, zarówno w sferze zawodowej, gdzie częste zmiany organizacyjne sprawiają, że z dnia na dzień można stracić stanowisko, gdzie prawie każdy zmienia pracę przynajmniej kilkakrotnie, szukając tej zapewniającej większe szeroko pojmowane bezpieczeństwo, jak i w sferze prywatnej, bowiem niejednokrotnie musi zmieniać miejsca zamieszkania, nie może zaplanować życia rodzinnego i osobistego. Zjawisko prekariatu dotyka szczególnie młodych i dobrze wykształconych ludzi: w warunkach wciąż wysokiego poziomu bezrobocia i niestabilności rynku pracy, powodowanej ciągłymi kryzysami, już na początku drogi zawodowej „wpadają" w system permanentnej niepewności, braku perspektyw, nie tylko rozwojowych, ale i socjalnych. Problem ten w jakimś stopniu wiąże się z zagrożeniami i bezpieczeństwem edukacyjnym, ponieważ, jak się wydaje, to nie tylko rynek pracy z nie zawsze realnymi oczekiwaniami wobec absolwentów, ale i polityka oraz system edukacyjny, z zakłóconymi proporcjami w kształceniu na różnych poziomach, przyczyniają się do marginalizacji potencjalnych innowatorów gospodarki. D. Nacjonalizm i ksenofobia oraz ekstremizm światopoglądowy, prowadzący do napięć oraz konfliktów wewnętrznych i międzypaństwowych. Tendencje separatystyczne i emancypacyjne, obserwowane od początku lat 90 . 
$\mathrm{XX}$ wieku, nie dotyczą tylko tzw. strefy poradzieckiej, gdzie powstało wiele nowych państw, lecz także Europy Zachodniej (Kraj Basków w Hiszpanii, Korsyka) oraz Afryki. Podziały terytorialne mają już nie tylko tło etniczne, lecz także religijne. Towarzyszą im akty ludobójstwa i masowe migracje ludności. Odrębny problem stanowią ruchy emancypacyjne, których celem jest demokratyzacja życia politycznego i społecznego, takie jak podczas arabskiej wiosny w Afryce Północnej. Mimo swej lokalności oddziałują one na bezpieczeństwo międzynarodowe, a przede wszystkim na człowieka i realizację jego praw. Nacjonalizm i ksenofobia najbardziej uwidoczniły się w ciągu trwających od kilku lat wielkich migracji, zwłaszcza ofiar wojny domowej w Syrii i Afryce Północnej oraz Środkowej. Ksenofobiczna i jawnie rasistowska postawa społeczeństw niektórych krajów UE ujawniła przy okazji skłonności do rodzenia się postaw skrajnie nacjonalistycznych, wręcz faszystowskich. E. Malejący przyrost naturalny i zwiększająca się liczba osób w wieku poprodukcyjnym, zwiększa ryzyko niewydolności systemu zabezpieczeń społecznych i zdrowotnych. Żaden system emerytalny czy opieki zdrowotnej nie jest w stanie wytrzymać zwiększających się kosztów utrzymania stale rosnącej rzeszy emerytów. Rodzić to może nie tylko problemy natury finansowej, lecz także społecznej, np. konflikty pomiędzy młodszymi i starszymi rocznikami itp. F. Pogarszający się stan środowiska naturalnego człowieka. Szybki wzrost i przenoszenie się przez granice państw skażeń różnych ekosystemów oraz wyczerpywanie się zasobów surowców nieodnawialnych systematycznie negatywnie wpływa na jakość życia ludzi, a nawet może stwarzać zagrożenia dla biologicznego przeżycia mieszkańców obszarów najbardziej ekologicznie zdegradowanych; może również komplikować sytuację wewnętrzną państw, rodzić spory i napięcia między państwami, a także zwiększać wrażliwość narodów i państw na innej natury zagrożenia dla ich bezpieczeństwa. G. Dominująca rola sektora finansowego w gospodarce. Od 2008 roku obserwuje się coraz większy wpływ sektora finansowego na funkcjonowanie gospodarek światowych, który przez tzw. kreatywną księgowość oraz nieetyczność swoich działań doprowadził z jednej strony do pogłębiania się rozwarstwienia społecznego, z drugiej zaś do zachwiania gospodarek. Stanowi on poważne źródło zagrożeń bezpieczeństwa społecznego, gospodarczego, politycznego, ale też militarnego. W społeczeństwie informacyjno-informatycznym wiadomości o roli sektora finansowego w kryzysie gospodarczym przyczyniają się nie tylko do powstawania ruchu oburzonych, lecz także mogą być przyczyną radykalizacji poglądów polityków hołdujących populizmowi, zamieszek społecznych, a nawet otwartej walki w imię haseł socjalnych. Konfrontacja własnego położenia socjalnego z innymi, lepiej uposażonymi społecznościami, możliwa dzięki mediom, może prowadzić do chęci wyrównania dysproporcji, nie zawsze pokojowymi, ergo ekonomicznymi metodami. 


\section{UWARUNKOWANIA AKTYWNOŚCI EDUKACYJNEJ DOROSŁYCH}

Wiele z wymienionych zagrożeń bezpieczeństwa społecznego nie tylko bezpośrednio wpływa na poczucie bezpieczeństwa jednostek i grup społecznych, lecz także tworzy zespół warunków sprzyjających nie tyle zwiększaniu, ile w ogóle istnieniu jakiekolwiek aktywności edukacyjnej dorosłych. Najczęściej bowiem wśród warunków wpływających na rozwój edukacji dorosłych, a także uczestnictwo w niej dorosłych, wskazuje się na czynniki związane z egzystencją jednostki, takie jak - stała praca i stabilizacja zawodowa; • warunki materialne zapewniające godne życie, ale też możliwość pokrycia opłat za kształcenie; • zdrowie własne i rodziny, pozwalające skupić się na edukacji; • pomoc i wsparcie w wychowywaniu dzieci, zarówno ze strony rodziny, jak i samorządu i państwa; • tolerancja i akceptacja społeczna dla różnych odmienności i dysfunkcjonalności (niepełnosprawność, odmienność rasowa czy etniczna, wiek); • system prawny sprzyjający podejmowaniu edukacji (ewaluacja i certyfikacja wykształcenia i kwalifikacji); • stan bazy edukacyjnej (publiczne i niepubliczne placówki edukacyjne, transport publiczny, dostępność i stan zbiorów bibliotecznych); • kapitał kulturowy dorosłych kandydatów do edukacji.

Poczucie bezpieczeństwa determinowane stanem środowiska bezpieczeństwa, statusem i sytuacją społeczną czy kompetencjami jednostki i poczuciem kontroli na własnym życiem i losem, obok osobowości dorosłego, są predykatorami aktywności edukacyjnej, równie ważnymi jak motywacja wynikająca z potrzeb pracy czy poczucia potrzeby samodoskonalenia, samorealizacji. Stan środowiska bezpieczeństwa obejmuje w perspektywie społecznej z jednej strony powiększającą się strefę ubóstwa, rozwarstwienie i polaryzację społeczną, marginalizację i wykluczenie społeczne, z drugiej zaś dyskryminacyjne formy zatrudnienia, naruszające prawa pracownicze czy malejący przyrost naturalny, zmuszający pracowników do przedłużania okresu zatrudnienia, szczególnie w sytuacji coraz większej niewydolności systemu zabezpieczeń społecznych. Można zatem na aktywność edukacyjną dorosłych spojrzeć przez pryzmat dominacji potrzeb rynku pracy i wydłużającego się życia Polek i Polaków, powodującego wzrost ilości czasu po zakończeniu aktywności zawodowej i towarzyszącej mu ofercie edukacyjnej, której celem jest zarówno zaspokajanie potrzeb poznawczych, jak i kompensacja poprzednich okresów edukacji. Realizacja niektórych przynajmniej programów edukacyjnych wymaga spełnienia podstawowych warunków, takich jak: stan zdrowia, pozwalający skupić się na edukacji, dostępność placówek oświatowych (np. domów dziennego pobytu, w którym dorośli, szczególnie starsi, mogą nie tylko uczyć się, lecz także rehabilitować zdrowotnie), odpowiednia ilość czasu, pozwalająca na edukację bez uszczerbku dla życia rodzinnego i prywatnego, dobry 
poziom materialny, gwarantujący, że podjęcie edukacji nie spowoduje zaniechania lub ograniczenia realizacji innych zobowiązań i potrzeb osobistych itp.

Warto także zwrócić uwagę na znaczenie kapitału kulturowego dla edukacji dorosłych, pojęcia zaproponowanego przez Pierre’a Bourdieu na określenie idei, wiedzy, umiejętności i przedmiotów o wartościach kulturowych, jakie ludzie nabywają, uczestnicząc w życiu społecznym. Wyraża się on przede wszystkim w językowych i kulturowych kompetencjach jednostki. Według Bourdieu występuje on w trzech podstawowych formach: (1) ucieleśnionej (embodied), jako długotrwałe dyspozycje ciała i umysłu, w tym w szczególności tzw. dobre maniery, gust kulturowy, smak, znajomość form kultury wysokiej, konwencji kulturowych i towarzyskich; (2) zinstytucjonalizowanej, głównie w postaci sformalizowanego wykształcenia, w szczególności potwierdzonego przez dyplomy prestiżowych uczelni; (3) uprzedmiotowionej (objectified), jako posiadane dobra kulturowe (malarstwo, książki, maszyny itp.) (Bourdieu 1986, 1990).

Zdaniem Barbary Fatygi kapitał kulturowy (capital culturel) zawiera całość dóbr symbolicznych i istnieje w trzech stanach czy postaciach. Po pierwsze jest to „kapitał inkorporowany, wcielony, zinternalizowany” - (incorporé), czyli wiedza (connaissances) tworząca trwałe dyspozycje jednostki - kompetencje. Przejawia się ona w formie kompetencji w jakiejś dziedzinie, poprawnym użyciu języka, znajomości konwencji, orientacji w świecie społecznym. Po drugie - „kapitał zobiektywizowany" (objectivé), czyli dziedzictwo kulturowe: dobra kultury w postaci materialnej, dostępne intersubiektywnie i dzięki temu podlegające dyfuzji w przestrzeni oraz transmisji międzypokoleniowej (obrazy książki, instrumenty, maszyny itd.). Trzecią postacią jest kapitał zinstytucjonalizowany (institutionalisé) poprzez uznanie społeczne - tytuły, dyplomy, zwycięstwa w konkursach. Społeczne oznacza tu raczej państwowe nadawanie statusu. Nabycie kapitału kulturowego wymaga nie tylko osobistej pracy jednostki, lecz także czasu i kapitału materialnego, ponieważ długa skolaryzacja jest kosztowna (Fatyga 2010, s. 35-36).

Nabycie i posiadanie kapitału kulturowego, zarówno ucieleśnionego, jak i uprzedmiotowionego jest przedmiotem troski zarówno jednostek, jak i społeczeństw, ponieważ stanowi on o stratyfikacji społecznej, a zarazem jest obiektem starań i pożądania osób nieposiadających go. W społeczeństwach postkomunistycznych nabywanie kapitału kulturowego jest postrzegane jako droga do awansu społecznego, ponieważ o stratyfikacji społecznej nie decyduje odziedziczony ani kapitał ucieleśniony (inkorporowany), ani uprzedmiotowiony (zobiektywizowany). W tej sytuacji największe znaczenie ma kapitał zinstytucjonalizowany, głównie $\mathrm{w}$ postaci sformalizowanego wykształcenia, potwierdzonego dyplomami, niekoniecznie najbardziej prestiżowych, uczelni. Ukształtowana w PRL ścieżka awansu, osadzona w wykształceniu, opierała się na antynomii: praca fizyczna versus praca 
umysłowa, z których to ta druga nobilitowała. Zdobycie wykształcenia, najlepiej wyższego, było substytutem nobilitacji opartej na tzw. starych pieniądzach czy budowanej przez pokolenia pozycji zawodowej (cechowej, dzisiaj powiedzielibyśmy korporacyjnej, np. lekarzy, prawników, naukowców itp.). Współcześnie, jak się wydaje, pozornie - w wyniku wysokiego stopnia skolaryzacji, zwłaszcza młodego pokolenia Polaków - wykształcenie powoli traci swój stratyfikujący charakter, niewątpliwie jednak nadal jest istotnym czynnikiem budowy kapitału kulturowego jednostek, grup społecznych i całego społeczeństwa.

Zachowanie i utrzymanie kapitału kulturowego jest jednym z warunków przetrwania społeczeństw, a przede wszystkim narodów. Drogą do zdobycia kapitału kulturowego jest nie tylko praca jednostki, lecz także, współcześnie, w zasadzie, permanentna edukacja. Tu jednak również można spotkać się z różnymi zagrożeniami, stąd tak ważne jest budowanie poczucia bezpieczeństwa edukacyjnego (safety education) obejmującego stan organizacyjno-prawny oraz programowy publicznych i niepublicznych instytucji edukacyjnych państwa, stowarzyszeń i organizacji oświatowych, a także mediów, zapewniający swobodny i niezagrożony dostęp do wiedzy i edukacji, której celem jest wielostronny rozwój osobowości jednostki. Dotyczy to zarówno zinstytucjonalizowanej edukacji dorosłych, jak i samorzutnej i samodzielnej aktywności edukacyjnej. W tym drugim przypadku ważne są jakość i treści edukacji. Można przypuszczać, że odziedziczony kapitał kulturowy w znacznym stopniu przyczynia się do, z jednej strony, poczucia bezpieczeństwa edukacyjnego, z drugiej zaś do podnoszenia i utrzymywania odpowiedniego poziomu edukacji dorosłych. Bowiem nabywanie i utrzymanie kapitału kulturowego opiera się na wychowaniu, w którym ogromną rolę odgrywa przekazywanie wzorów i kształtowanie etosu danej grupy społecznej (np. rodziny, grupy zawodowej, odpowiednika klasy społecznej). Aktywność edukacyjna jest wówczas naturalnym i oczywistym rodzajem aktywności ludzkiej.

\section{PODSUMOWANIE}

Nawet pobieżny przegląd literatury andragogicznej, a także obserwacja rzeczywistości społecznej i edukacyjnej dostarcza danych do sformułowania tezy, że o aktywności edukacyjnej dorosłych decydują głownie: (1) potrzeby i zainteresowania edukacyjne oraz potrzeby poznawcze dorosłych; (2) społeczne i ekonomiczne uwarunkowania możliwości zaspokajania potrzeb edukacyjnych dorosłych; (3) możliwości zaspokojenia potrzeb edukacji dorosłych tkwiące w bazie edukacyjnej; (4) społeczny klimat wokół edukacji dorosłych. O wyborze problematyki będącej przedmiotem edukacji najczęściej decydują potrzeby zawodowe. Trudno się jednak 
oprzeć wrażeniu, że ważną rolę odgrywają także nawyki i potrzeby poznawcze potrzeba uczenia się, rozumienia zmieniającego się otoczenia, dotrzymywania kroku przemianom cywilizacyjnym, kulturowym i technologicznym. Jednak chyba w największym stopniu potrzeba uczenia się, nawyk czytania, potrzeby poznawcze.

Wskaźniki aktywności edukacyjnej ilustrują tylko pewien trend, nie informując o charakterze aktywności edukacyjnej, ani tym bardziej o treściach uczenia się. Ważniejsze wydają się wskaźniki dotyczące umiejętności podstawowych: czytania, pisania i liczenia, bowiem wskazują one na skalę wtórnego analfabetyzmu, którego nie da się wytłumaczyć używaniem np. kalkulatora do liczenia czy klawiatury komputera do pisania. Tym bardziej, że aby na niej pisać, trzeba znać litery.

\section{LITERATURA}

Booth K., Security and Emancipation. „Review of International Studies”, vol. 17. Bourdieu P., Passeron J.-C., 1990, Reprodukcja: elementy teorii systemu nauczania. Warszawa, PWN.

Bourdieu P., 1986, The forms of capital. W: J.G. Richardson (red.), Handbook of theory and research for sociology of education. New York, Westport, Connecticut, London: Greenwood Press.

Buzan B., 1983, Poeple States and Fear. The National Security Problem in International Relations, Brighen.

Fatyga B., 2010, Kapitat kulturowy. W: A. Matuchniak-Krasuska, Zarys socjologii sztuki Pierre'a Bourdieu. Warszawa, Oficyna Naukowa.

Gardocki L., 1999, Obrona konieczna, czyli triumf prawa nad bezprawiem. „Rzeczpospolita", nr 142.

Human Development Report 1994, Publishet for the United Nations Development Programme (UNDP). New York Oxford, Oxford University Press.

Jarosz M., 2008, Obszary wykluczenia w Polsce. W: Wykluczeni, wymiar społeczny, materialny i etniczny. Warszawa, Instytut Studiów Politycznych PAN.

Klamut R., 2012, Bezpieczeństwo jako pojecie psychologiczne. „Zeszyty Naukowe Politechniki Rzeszowskiej. Ekonomia i Nauki Humanistyczne", nr 286, z. 19 (4/2012).

Komisja Europejska /EACEA/Eurydice, 2015. Adult Education and Training in Europe: Widening Access to Learning Opportunities. (Edukacja i szkolenia dorosłych w Europie: zwiększanie dostępu do możliwości uczenia się) Raport Eurydice. Luksemburg: Urząd Publikacji Unii Europejskiej.

Korzeniowski L.F., 2008, Securitologia. Nauka o bezpieczeństwie człowieka i organizacji społecznych. Kraków. 
GUS, 2013, Kształcenie dorostych. Warszawa.

Marciniak E.M., 2009, Psychologiczne aspekty poczucia bezpieczeństwa. W: S. Sulowski, M. Brzeziński, Bezpieczeństwo wewnętrzne państwa. Wybrane zagadnienia. Warszawa.

Maslow A., 2009, Motywacja i osobowość. Warszawa.

Monitor kształcenia i szkolenia, 2015, Polska, Urząd Publikacji Unii Europejskiej, Luksemburg.

Narodowa Strategia Integracji Społecznej dla Polski, 2003, Warszawa.

Pokruszyński W., 2010, Teoretyczne aspekty bezpieczeństwa. Józefów.

Sillamy N., 1996, Słownik psychologii. Katowice.

Standing G., 2017, Prekariat. Nowa niebezpieczna klasa. Warszawa, Wydawnictwo Naukowe PWN.

Tomiło J., 2015, Edukacja dla bezpieczeństwa w perspektywie antropocentrycznej. Piotrków Trybunalski, NWP.

Uchnast Z., 1990, Metoda pomiaru bezpieczeństwa. W: A. Januszewski, Z. Uchnast, T. Witkowski (red.), Wykłady z psychologii w KUL, t. 5, Lublin.

Urbanek A., 2013, Wybrane problemy bezpieczeństwa. Dziedziny bezpieczeństwa. Słupsk.

Wójcik Z., 2003, Poczucie bezpieczeństwa a niepokój u młodzieży. „Prace naukowe Wyższej Szkoły Pedagogicznej w Częstochowie” seria: Psychologia, z. X.

\title{
NETOGRAFIA:
}

http://epp.eurostat.ec.europa.eu

\section{SOME CONDITIONS FOR ADULT EDUCATIONAL ACTIVITY}

\begin{abstract}
The low rate of adult educational activity, observed for years, prompts reflection on the causes of this phenomenon - making a diagnosis that could become a canvas for actions aimed at eliminating these causes. The article focuses on the attempt to show the determinants of educational activity of adults. Two types of factors were considered to play a significant role here related to the sense of security: personal, work or educational and related to the cultural capital of the individual. The sense of security is identified through the prism of the state of the security environment, status and social situation as well as the competences of the individual and a sense of control over one's life and fate, as well as the personality of an adult. The state of the security environment has been shown in a social perspective through an increasing poverty zone, social stratification and polarization, marginalization and social exclusion, as well as
\end{abstract}


discriminatory forms of employment, violating labor rights and decreasing natural growth, forcing employees to extend the employment period, especially in the situation of increasing inefficiency social security system. It was proposed to look at the educational activity of adults through the prism of the dominance of the needs of the labor market, but also the longer life of Polish women. In contrast, the importance of cultural capital is manifested in social stratification: in post-communist societies, the acquisition of cultural capital is seen as a way to social advancement, because social stratification is not determined by inherited capital as well as objectified. In this situation, institutionalized capital is the most important, mainly in the form of formal education confirmed by university diplomas. The promotion path formed in the People's Republic of Poland, embedded in education, was based on antinomy: physical labor versus intellectual work, the latter of which ennobled. Obtaining education, preferably higher, was a substitute for ennoblement based on the so-called old money or a professional position built over generations.

Keywords: adult education, sense of security, cultural capital, adult educational activity 